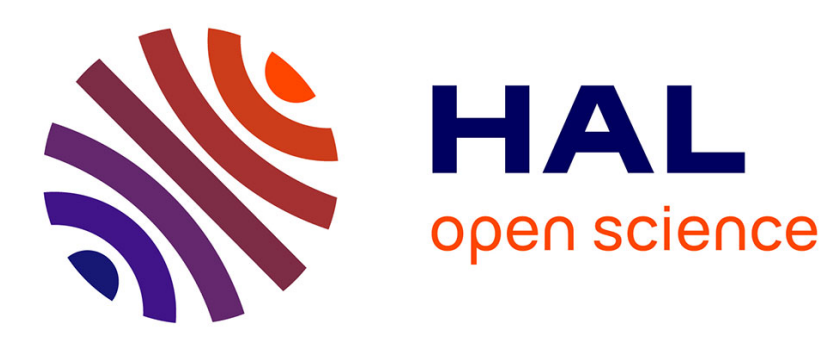

\title{
Are fecal stanols suitable to record and identify a pulse of human fecal contamination in short-term exposed shellfish? A microcosm study
}

\author{
Loic Harrault, Emilie Jardé, Laurent Jeanneau, Patrice Petitjean
}

\section{- To cite this version:}

Loic Harrault, Emilie Jardé, Laurent Jeanneau, Patrice Petitjean. Are fecal stanols suitable to record and identify a pulse of human fecal contamination in short-term exposed shellfish? A microcosm study. Marine Pollution Bulletin, 2014, 89 (1-2), pp.40-48. 10.1016/j.marpolbul.2014.10.037 . insu01117210

\author{
HAL Id: insu-01117210 \\ https://hal-insu.archives-ouvertes.fr/insu-01117210
}

Submitted on 16 Feb 2015

HAL is a multi-disciplinary open access archive for the deposit and dissemination of scientific research documents, whether they are published or not. The documents may come from teaching and research institutions in France or abroad, or from public or private research centers.
L'archive ouverte pluridisciplinaire HAL, est destinée au dépôt et à la diffusion de documents scientifiques de niveau recherche, publiés ou non, émanant des établissements d'enseignement et de recherche français ou étrangers, des laboratoires publics ou privés. 
Elsevier Editorial System(tm) for Marine Pollution Bulletin Manuscript Draft

Manuscript Number: MPB-D-14-00683R2

Title: Are fecal stanols suitable to record and identify a pulse of human fecal contamination in shortterm exposed shellfish? A microcosm study.

Article Type: Research Paper

Keywords: Oyster,Fecal contaminationSeawaterFecal stanolsPersistenceMicrocosms

Corresponding Author: Dr. Loïc Harrault, Ph.D

Corresponding Author's Institution: CNRS, Géosciences Rennes

First Author: Loïc Harrault, Ph.D

Order of Authors: Loïc Harrault, Ph.D; Emilie Jardé; Laurent Jeanneau; Patrice Petitjean

Abstract: In this study, the capacity of oysters to bioaccumulate fecal stanols and to record a sourcespecific fingerprint was investigated by the short-term contamination of seawater microcosms containing oysters with a human effluent. Contaminated oysters bioaccumulated the typical fecal stanols coprostanol and 24-ethylcoprostanol and their bioaccumulation kinetics were similar to that of the Fecal Indicator Bacteria Escherichia coli used in European legislation. Although stanol fingerprints of contaminated water allowed the identification of the human specific fingerprint, this was not the case for oysters. This discrepancy is attributed to i) high concentrations of endogenous cholestanol and sitostanol, responsible for "unbalanced" stanol fingerprints, ii) different accumulation/depuration kinetics of fecal coprostanol and 24-ethylcoprostanol and iii) the limits of the analytical pathway used. These results show that fecal stanols bioaccumulated by oysters are useful to record fecal contamination but the usefulness of stanol fingerprints to identify specific sources of contamination in shellfish currently seems limited. 
Highlights:

- Oysters were fecally-contaminated with human wastewater in seawater microcosms.

- Stanol concentrations and fingerprints were analyzed in both the water and oysters.

- Fecal stanols coprostanol and 24-ethylcoprostanol were bioaccumulated by the oysters.

- The human-specific stanol fingerprint of water was not transferred to the oysters. 
Title: Are fecal stanols suitable to record and identify a pulse of human fecal contamination in short-term exposed shellfish? A microcosm study.

Loïc Harrault*, Emilie Jardé, Laurent Jeanneau and Patrice Petitjean

CNRS, UMR 6118 Geosciences Rennes, Campus de Beaulieu, 35042 Rennes Cedex, France

Keywords: Oyster, fecal contamination, seawater, fecal stanols, persistence, microcosms.

Highlights:

- Oysters were fecally-contaminated with human wastewater in seawater microcosms.

- Stanol concentrations and fingerprints were analyzed in both the water and oysters.

- Fecal stanols coprostanol and 24-ethylcoprostanol were bioaccumulated by the oysters.

- The human-specific stanol fingerprint of water was not transferred to the oysters.

* corresponding author:

Email: loic.harrault@gmail.com 


\begin{abstract}
In this study, the capacity of oysters to bioaccumulate fecal stanols and to record a source-specific fingerprint was investigated by the short-term contamination of seawater microcosms containing oysters with a human effluent. Contaminated oysters bioaccumulated the typical fecal stanols coprostanol and 24-ethylcoprostanol and their bioaccumulation kinetics were similar to that of the Fecal Indicator Bacteria Escherichia coli used in European legislation. Although stanol fingerprints of contaminated water allowed the identification of the human specific fingerprint, this was not the case for oysters. This discrepancy is attributed to i) high concentrations of endogenous cholestanol and sitostanol, responsible for "unbalanced" stanol fingerprints, ii) different accumulation/depuration kinetics of fecal coprostanol and 24-ethylcoprostanol and iii) the limits of the analytical pathway used. These results show that fecal stanols bioaccumulated by oysters are useful to record fecal contamination but the usefulness of stanol fingerprints to identify specific sources of contamination in shellfish currently seems limited.
\end{abstract}




\section{Introduction}

In coastal environments, shellfish can bioaccumulate pathogenic micro-organisms associated with human and animal fecal contamination originating from the watershed (Fong and Lipp, 2005; Hundesa et al, 2005; Riou et al., 2007; Soller et al., 2010). This type of fecal contamination can result in sanitary risks due to the consumption of contaminated shellfish and has led European authorities to impose a shellfish classification based on the fecal indicator bacteria (FIB) Escherichia coli (E. coli, European Shellfish Directive 91/492/CEE). In addition, the European Shellfish Directive on shellfish harvesting (854/2004/EC) requires the identification of potential sources of fecal contamination in these environments.

Since E. coli is not source-specific, microbial source tracking methods were developed combining microbial and chemical markers to identify the sources of fecal pollution (Simpson et al., 2002; Glassmeyer et al., 2005; Blanch et al., 2006; Vogel et al., 2007; Gourmelon et al., 2010). These methods have been successfully used in several environmental matrices (e.g. water, soil, and sediment), but they remained poorly applied to shellfish and in these latter cases, they only involved microbial markers (Vantarakis et al., 2006; Wolf et al., 2010; Mieszkin et al., 2013). Consequently, chemical markers have not yet been applied to directly identify the sources of fecal contamination in shellfish.

Fecal stanols are direct chemical markers from animal feces. Their distribution in feces depends on i) the animal's diet, ii) the ability of animals to biosynthesize endogenous sterols and iii) the composition of the intestinal flora responsible for sterol biohydrogenation into stanols (Leeming et al., 1996). This species-specific distribution, called the "stanol fingerprint" has been successfully used, via the analysis of stanol ratios or by multivariate analyses, to distinguish between human and animal fecal contamination in water, soil, and 
sediment (Bull et al., 2002; Jardé et al., 2007; Shah et al., 2007; Jardé et al., 2009; Tyagi et al., 2009; Gourmelon et al., 2010, Derrien et al., 2011, 2012; Biache and Philp, 2013). Moreover, stanols are sufficiently persistent in the environment to be transferred from the watershed to seawater where the shellfish are living (Solecki et al., 2011; Jeanneau et al., 2012).

In shellfish, studies that investigated the use of fecal stanols to track human contamination focused on the human-associated coprostanol (Sherwin et al., 1993; Cathum and Sabik, 2001; Gagné et al., 2001, 2002; Hellou et al., 2003; Yeats et al., 2008), but the usefulness of the stanol fingerprint to identify human-specific contamination remains unknown. Recently, Harrault et al. (2014) applied the principal component analysis (PCA) model developed by Derrien et al. (2011) to oysters collected in Brittany, which can be used to distinguish between human, porcine and bovine fecal contamination in water in Brittany (Derrien et al., 2012). Harrault et al. (2014) found that oysters fecally contaminated by the FIB E. coli presented a specific bovine fingerprint while non-contaminated oysters have no specific fingerprint. However, the transfer of a specific stanol fingerprint from the surrounding water to oyster tissue, in controlled conditions, has not been yet investigated and their persistence has not been compared to that of $E$. coli which are requirements for using them as reliable markers to identify sources of fecal contamination (Blanch et al., 2006).

The present study was conducted to evaluate these issues. In an experimental design conducted in microcosms, the persistence of selected stanols was compared to that of the FIB E. coli in seawater initially contaminated with wastewater treatment plant (WWTP) influent and in oysters. In addition, under these experimental conditions, the efficiency of the stanol ratios and Derrien et al.'s (2011) PCA model were investigated to track the human-specific contamination of water and oysters exposed to a short-term contamination.

\section{Material and methods}




\subsection{Reagent and chemicals}

Organic solvents were of high performance liquid chromatography (HPLC) grade. Dichloromethane (DCM) was purchased from Carlo-Erba SDS (Val de Reuil, France), methanol $(\mathrm{MeOH})$, isopropanol, hydrochloric acid 37\% and cyclohexane were purchased from VWR (West Chester, PA). N,O-bis- (trimethylsilyl)trifluoroacetamide and trimethylchlorosilane (99/1, v/v) (BSTFA + TMCS) and SPE disks (Supelco ENVI-18DISK, $47 \mathrm{~mm}$ in diameter) were purchased from Supelco (St. Quentin Fallavier, France).

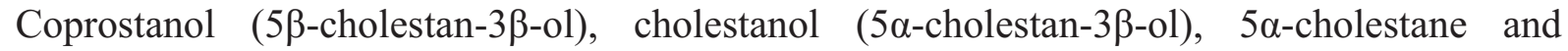
anhydrous magnesium sulfate $\left(\mathrm{MgSO}_{4}\right)$ were purchased from Sigma (St. Quentin Fallavier,

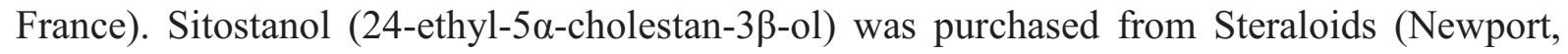
United States). 24-Ethylcoprostanol (24-ethyl-5 $\beta$-cholestan-3 $\beta$-ol) and 24-ethylepicoprostanol (24-ethyl-5 $\beta$-cholestan-3 $\alpha$-ol) were purchased from BCP Instruments (Irigny, France). Silica gel (40-63 $\mu \mathrm{m})$ was purchased from Merck (Darmstadt, Germany). Cholesterol $\mathrm{d}_{6}$ $\left(\left[2,2,3,4,4,6-{ }^{2} \mathrm{H}_{6}\right]\right.$-cholest-5-en-3 $\beta$-ol) was purchased from CDN Isotopes (Pointe-Claire, Canada).

\subsection{Incubations and sampling}

Five-hundred and sixteen oysters (Crassostrea gigas) were purchased in Cancale (France), $200 \mathrm{~L}$ of seawater was sampled at Dinard (France) and $30 \mathrm{~L}$ of raw WWTP sewage was sampled at Acigné (France) in January 2013. In the laboratory, oysters were placed in 43 11-liter plastic boxes $(39.5 \times 26.5 \times 15.6 \mathrm{~cm}, \mathrm{~L} \times 1 \times \mathrm{h})$ pre-washed with distilled water and ethanol to remove any plasticizers. Twelve oysters were submerged in each box filled with 4 
$\mathrm{L}$ of unfiltered seawater. This volume corresponds to more than $300 \mathrm{~mL}$ of seawater per oyster, which is necessary for their survival in controlled conditions (Mauffret et al., 2013). Batches were continuously oxygenated using aquarium pumps and kept in the dark to avoid phytoplankton development and photodegradation of the organic compounds. At the beginning of the experiment, oysters were allowed to acclimate to laboratory conditions for $72 \mathrm{~h}$ (Charles et al., 1992).

The experiment began by diluting the raw WWTP sewage to $10 \%$ ("10\%" treatment thereafter) in 18 batches and $20 \%$ (" $20 \%$ " treatment thereafter) in 18 other batches. The remaining batches without WWTP sewage addition were used as blanks. Except at the beginning of the experiment (0h), 1 "blank" batch and 3 batches (triplicates) for both the " $10 \% "$ and " $20 \% "$ treatments were sampled at each sampling time. At $0 \mathrm{~h}$, oysters sampled from the "blank" batch were considered as $0 \mathrm{~h}$ samples for the "blank", "10\%" and "20\%" treatments. The water and oysters were sampled at $1 \mathrm{~h}, 6 \mathrm{~h}, 24 \mathrm{~h}, 48 \mathrm{~h}, 196 \mathrm{~h}$ ( 8 days) and $332 \mathrm{~h}$ (14 days) after the start of the experiment. At each sampling time, the 12 oysters from the sampled batches were collected for E. coli and stanol analyses and $2.5 \mathrm{~L}$ of the water was sampled for E. coli and chemical analyses including dissolved organic carbon analysis, suspended particulate matter concentrations, and dissolved stanol analyses. Results for the " $10 \%$ " and " $20 \%$ " treatments are the means of the three replicates.

\subsection{Physico-chemical parameters}

Suspended particulate matter concentrations were determined by filtrating the water samples through pre-weighted glass-fiber filters at $0.7 \mu \mathrm{m}$. Filters were freeze-dried and weighed to determine the particle concentrations. Dissolved organic carbon concentrations were determined on filtered $(0.7 \mu \mathrm{m})$ water samples using a Shimadzu TOC 5050 total carbon 
analyzer (Noisiel, France). Dissolved oxygen, $\mathrm{pH}$, salinity and temperature were measured throughout the experiment using a multisensor probe (WTW, Ales, France).

\subsection{Escherichia coli analysis}

The concentration of the FIB E. coli was determined by the CVPA laboratory (SaintMalo, France) using culture methods (NF EN ISO 9308-3 for the water and NF V08 600 for the oysters). These methods required $500 \mathrm{~mL}$ of the water samples and six living oysters. Due to technical constraints, E. coli counts were limited to an upper limit of $4.5 \log _{10}$ colony forming units (log CFU) per $100 \mathrm{~mL}$ for the water and $4.2 \log$ CFU per $100 \mathrm{~g}$ of flesh for the oysters.

\subsection{Stanol extraction and analysis}

\subsubsection{Water}

Solid phase extractions (SPE) were performed to extract fecal stanols from filtered $(0.7$ $\mu \mathrm{m}$ glass-fiber) water samples as described by Jeanneau et al. (2011). Briefly, known amounts of the recovery standard cholesterol $\mathrm{d}_{6}$ were added to $1 \mathrm{~L}$ of filtered water samples before adjusting its $\mathrm{pH}$ to 1 with a $1 \mathrm{M}$ hydrochloric acid solution and the addition of $100 \mathrm{~mL}$ of isopropanol. Then, the mixture was passed through pre-washed (DCM) and activated (MeOH) SPE disks. Stanols bound to the disk were eluted with DCM and analyzed by gas chromatography-mass spectrometry (GC-MS).

\subsubsection{Oysters}


Stanols from oyster tissue were extracted and analyzed as described by Harrault et al. (2014). Briefly, the oyster flesh (about 4 g dry weight, DW) was freeze-dried and ground and the total lipids were extracted using an Accelerated Solvent Extractor (ASE 200, Dionex, Courtaboeuf, France) with DCM. Then, the total lipids were fractionated on silica gel columns into an apolar fraction eluted with a mixture of cyclohexane/DCM (2/1, v/v) and a stanol-containing polar fraction eluted with a mixture of DCM/MeOH $(1 / 1, \mathrm{v} / \mathrm{v})$.

\subsubsection{Stanol analysis using gas chromatography-mass spectrometry (GC-MS)}

Stanols extracted from the water and oyster samples were derivatizated using a mixture of BSTFA + TMCS $(99 / 1, \mathrm{v} / \mathrm{v})$ at $60^{\circ} \mathrm{C}$ for 20 minutes to convert hydroxyl groups into trimethylsilyl (TMS) ether groups. Derivatizated stanols were then analyzed by GC-MS with a Shimadzu QP2010 + MS gas chromatograph/mass spectrometer (Shimadzu, Tokyo, Japan) with electron ionization at $70 \mathrm{eV}$. Separation was achieved using a fused silica column coated with SLB-5 MS (Supelco, $60 \mathrm{~m}$, i.d. $0.25 \mathrm{~mm}$, film thickness $0.25 \mu \mathrm{m}$ ) with helium as a carrier gas at a flow of $1 \mathrm{ml} \mathrm{min}{ }^{-1}$. The GC oven temperature was maintained at $70^{\circ} \mathrm{C}$ for 1 min, then increased to $130^{\circ} \mathrm{C}$ at $15{ }^{\circ} \mathrm{C} \min ^{-1}$, then to $300^{\circ} \mathrm{C}$ at $3{ }^{\circ} \mathrm{C} \min ^{-1}$ and held at this temperature for $15 \mathrm{~min}$. Analyses were performed in SIM (selective ion monitoring) mode. Quantification was based on the internal standard ( $5 \alpha$-cholestane) method and a five-point calibration curve was used (standards: coprostanol, epicholestanol, epicoprostanol, cholestanol and sitostanol). The limits for the quantifications were $0.1 \mu \mathrm{g} / \mathrm{L}$ for the water and $5 \mu \mathrm{g} / \mathrm{g}$ DW for the oysters.

2.6. Stanol ratios 
In order to investigate the usefulness of fecal stanols to record a specific human contamination in water and shellfish, three ratios for the fecal stanol concentrations were used:

- $\quad R 1=\frac{[\text { Coprostanol }]}{[\text { Cholestanol }]}$. With R1 considered as specific from human contamination when $>$ 0.50 (Shah et al., 2007; Furtula et al., 2012 and references therein).

- $\quad R 2=\frac{[\text { Coprostanol }]}{([\text { coprostanol }]+[24-\text { Ethylcoprostanol }])}$. With $\mathrm{R} 2$ considered as specific from human contamination when $>0.73$ (Leeming et al., 1997, Furtula et al., 2012 and references therein).

$-R 3=\frac{[\text { [itostanol }]}{[\text { Coprostanol }]}$. With R3 considered as specific from human contamination when $<0.20$ (Gourmelon et al., 2010).

\subsection{Statistical analyses}

Statistical analyses were performed using the $\mathrm{R}$ software (2.15.3, http://www.rproject.org/). Two-way ANOVAs, with treatment and time as explanatory variables, were performed to compare the evolution of the stanol concentrations in water and oysters between treatments. When the " $10 \%$ " and/or " $20 \%$ " treatments had a significant effect on the concentrations compared to the blank, post-hoc Tukey's tests were performed to compare one treatment to another. Data were log-transformed when necessary to normalize distributions and homogenize variances. A significant threshold of $\mathrm{p}<0.05$ was chosen for all analyses. 
Stanol fingerprints of the water and oysters were investigated using the PCA model set up by Derrien et al. (2011) with XLSTAT 2013 (Addinsoft, Paris, France). Briefly, this model is based on the distribution of six main fecal stanols (i.e., coprostanol, epicoprostanol, 24ethylcoprostanol, 24 ethylepicoprostanol, campestanol, and sitostanol) from 88 various samples of bovine, porcine (feces, manures, slurries, etc.) and human origin (raw and diluted waste water treatment plant effluent, sewage sludge). With $78.3 \%$ of the total variance explained by the first two components, this model distinguishes stanol fingerprints from the three previous origins into three distinctive clusters, allowing the identification of the origin of fecal contamination in the environmental matrix between bovine, porcine and human contamination. Each source sample was used as an individual and the water and oyster samples were used as supplementary individuals.

\section{Results}

\subsection{Physico-chemical parameters of water}

The mean values of the physico-chemical parameters of water throughout the experiment are presented in Table 1. The dissolved oxygen, $\mathrm{pH}$, temperature and suspended particulate matter concentration remained similar between all treatments over time. The different dilution factors between seawater and WWTP sewage in the "10\%" and "20\%" batches resulted in decreasing salinity and increasing dissolved organic carbon concentrations in water from the "blank" up to the " $20 \%$ " batches.

\subsection{Escherichia coli concentrations}




\subsubsection{Water}

The concentration of $E$. coli in the seawater and raw WWTP effluent was respectively 1.7 and $7.3 \log$ CFU/100 mL (Supplementary Table 1). Except at $1 \mathrm{~h}$ after the start of the experiment $(2.8 \log \mathrm{CFU} / 100 \mathrm{~mL})$, the concentration of $E$. coli in the non-contaminated water sample remained lower than the European threshold indicative of fecal contamination $(2.7 \log$ CFU/100 mL, Figure 1a). Until $48 \mathrm{~h}$ after the start of the artificial contamination, the concentration of $E$. coli in the " $10 \%$ " and "20\%" water samples $(4.5 \pm 0.0 \log$ CFU/100 mL) was higher than $2.7 \log \mathrm{CFU} / 100 \mathrm{~mL}$. Then their concentrations decreased below $2.7 \log$ $\mathrm{CFU} / 100 \mathrm{~mL}$ to reach low levels of contamination with $2.3 \pm 0.2 \log \mathrm{CFU} / 100 \mathrm{~mL}$ at $196 \mathrm{~h}$ and $1.2 \pm 0.0 \log \mathrm{CFU} / 100 \mathrm{~mL}$ at $332 \mathrm{~h}$ for the " $10 \%$ " water samples and $1.8 \pm 0.3 \log$ $\mathrm{CFU} / 100 \mathrm{~mL}$ at $196 \mathrm{~h}$ and $1.3 \pm 0.3 \log \mathrm{CFU} / 100 \mathrm{~mL}$ at $332 \mathrm{~h}$ for the " $20 \%$ " water samples (Figure 1a).

\subsubsection{Oysters}

The "blank" oysters were not fecally contaminated since their concentrations of E. coli were below the limit of quantification for the method used, except at $48 \mathrm{~h}$ with a concentration of $2.5 \log$ CFU/100 g, which remained lower than the European threshold indicative of fecal contamination of shellfish $(3.7 \log \mathrm{CFU} / 100 \mathrm{~g}$, Figure $1 \mathrm{~b})$. At the start of the experiment, the " $10 \%$ " and " $20 \%$ " oysters were not fecally contaminated (below the limit of quantification for both, Figure $1 \mathrm{~b}$ ) but from $1 \mathrm{~h}$ to $48 \mathrm{~h}$, they were both highly contaminated since their concentration of $E$. coli was higher than $3.7 \log$ CFU/100 g (4.2 $\pm 0.0 \log$ CFU/100 $\mathrm{g}$ for both 
treatments, Figure 1b). Then, the concentration of E. coli in the " $10 \%$ " oysters decreased below the contamination threshold at $196 \mathrm{~h}(3.0 \pm 0.4 \log \mathrm{CFU} / 100 \mathrm{~g})$ until $332 \mathrm{~h}(2.8 \pm 0.4 \log$ CFU/100 g). The concentration of $E$. coli in the "20\%" oysters decreased below the contamination threshold at $196 \mathrm{~h}(3.3 \pm 0.3 \log \mathrm{CFU} / 100 \mathrm{~g})$ and increased at the end of the experiment to reach $3.5 \pm 0.1 \log \mathrm{CFU} / 100 \mathrm{~g}$ at $332 \mathrm{~h}$.

\subsection{Stanol concentrations}

This section presents the temporal concentration variations in water and oysters of four particularly interesting stanols (Figure 2): coprostanol, 24-ethylcoprostanol, cholestanol and sitostanol. Coprostanol and 24-ethylcoprostanol were chosen because they are the two main fecal stanols of WWTP sewage $(71 \%$ and $15 \%$ of the total stanols, respectively, Supplementary Table 1) and thus are used as qualitative biomarkers of human fecal contamination. Cholestanol and sitostanol were chosen because they are the main stanols in the oysters quantified in this study (Supplementary Table 3). Individual concentrations of all stanols quantified in the water and oysters are presented in Supplementary Tables 2 and 3, respectively.

\subsubsection{Water}

On average throughout the experiment, the addition of WWTP sewage in seawater had a significant effect on the concentration of coprostanol, 24-ethylcoprostanol, cholestanol and sitostanol in water (treatment effect: $p<0.0001$ for the four compounds, Figure $2 \mathrm{a}, \mathrm{b}, \mathrm{c}, \mathrm{d}$ ): "blank" concentrations were lower than the "10\%" ones (Tukey tests: $p<0.0001$ for the four 
compounds), which were lower than the "20\%" ones (Tukey tests: $p<0.0001, p<0.001, p<$ 0.01 and $p<0.0005$, respectively).

In non-contaminated water, the concentration of coprostanol, 24-ethylcoprostanol, cholestanol and sitostanol slightly varied over time and remained below $0.14,0.45,1.83$ and $0.12 \mu \mathrm{g} / \mathrm{L}$, respectively (Figure $2 \mathrm{a}, \mathrm{b}, \mathrm{c}, \mathrm{d}$ ).

On the contrary, the concentration of these four compounds in the " $10 \%$ " and " $20 \% "$ water batches had high temporal variations which occurred at three different rates (time effect: $p<0.0001$ for the four compounds, Figure 2a, b, c, d): on average, their concentrations first increased by $951 \%$ until $48 \mathrm{~h}$, then decreased by $95 \%$ until $196 \mathrm{~h}$ and finally stabilized until 332h (Supplementary Table 2).

\subsubsection{Oysters}

Throughout the whole experiment, the concentration of both coprostanol and 24ethylcoprostanol in the " $10 \%$ " and " $20 \%$ " oysters were on average higher than those of the "blank" oysters (treatment effect: $p=0.002$ and $p=0.025$, respectively) but there was no significant dose effect between the "10\%" and "20\%" treatments (Tukey: $p=0.49$ and $p=$ 0.61, respectively; Table 2e, f; Supplementary Table 3). In addition, the kinetics of these two compounds were quite similar (time effect: $p<0.0001$ for the four modalities): their mean concentration increased by $154 \%$ from $0 \mathrm{~h}$ to $24 \mathrm{~h}$ or $48 \mathrm{~h}$ and then decreased by $38 \%$ until $332 \mathrm{~h}$.

Throughout the whole experiment, cholestanol was by and large the main stanol in the oyster tissue (ca. $450 \mu \mathrm{g} / \mathrm{g}$ DW and ca. $80 \%$ of the total stanols, Supplementary Table 3) and its concentrations exhibited high standard deviations (i.e. $17 \%$ of the mean relative standard 
deviation). Moreover, the concentration of cholestanol in oysters for the three treatments did not follow a specific trend (time effect: $p=0.84$, Figure $2 \mathrm{~g}$ ) and was similar among the treatments (treatment effect: $p=0.42$ ).

The sitostanol concentration in oysters tended to increase from the start until the end of the experiment (time effect: $p<0.0001,36.05 \mu \mathrm{g} / \mathrm{g} \mathrm{DW}$ at $0 \mathrm{~h}$ to ca. $80 \mu \mathrm{g} / \mathrm{g} \mathrm{DW}$ at $332 \mathrm{~h}$, Figure $2 \mathrm{~h}$ ) but did not differ between non-contaminated and contaminated microcosms (treatment effect: $p=0.26$ ).

\subsection{Stanol fingerprints}

\subsubsection{Water}

The maximum values for the R1 and R2 ratios in "blank" water were respectively 0.16 and 0.28 at $6 \mathrm{~h}$, which remains below the thresholds indicative of a major human contamination ( 0.50 for R1, 0.73 for R2, respectively; Figures 3a, b). Similarly, the minimum value for the R3 ratio in "blank" water was 0.50 at $332 \mathrm{~h}$, which remains above the 0.20 threshold indicative of a major human contamination (Figure 3c).

The R1 ratio value for " $10 \%$ " and " $20 \%$ " water decreased from $0 \mathrm{~h}$ to $6 \mathrm{~h}$ (from 16.53 to $2.35 \pm 0.83$ and 9.53 to $4.96 \pm 1.40$, respectively), then respectively increased to $4.04 \pm 0.29$ until $48 \mathrm{~h}$ and to $6.13 \pm 0.38$ until $24 \mathrm{~h}$, greatly decreased to $0.34 \pm 0.07$ and $0.37 \pm 0.07$ until 196h and finally decreased to $0.09 \pm 0.04$ and $0.04 \pm 0.00$ until $332 \mathrm{~h}$.

The R2 ratio value for " $10 \%$ " water decreased from $0 \mathrm{~h}(0.90)$ to $6 \mathrm{~h}(0.76 \pm 0.03)$, then increased to $0.83 \pm 0.01$ until $48 \mathrm{~h}$ and finally decreased to $0.21 \pm 0.08$ until $332 \mathrm{~h}$. The R2 
ratio value for " $20 \%$ " water decreased from $0 \mathrm{~h}(0.87)$ to $6 \mathrm{~h}(0.82 \pm 0.00)$, then remained constant until $48 \mathrm{~h}$ and finally decreased to $0.10 \pm 0.02$ until $332 \mathrm{~h}$.

For " $10 \%$ " and " $20 \%$ " water, the R3 ratio values increased from $0 \mathrm{~h}(0.02$ and 0.01 , respectively) to $1 \mathrm{~h}(0.10 \pm 0.03$ and $0.05 \pm 0.01$, respectively), then both slightly decreased to $0.03 \pm 0.00$ until $48 \mathrm{~h}$, slightly increased to respectively $0.26 \pm 0.02$ and $0.22 \pm 0.02$ until $196 \mathrm{~h}$ and finally greatly increased to $1.71 \pm 0.50$ and $3.07 \pm 0.54$, respectively, until $332 \mathrm{~h}$.

The projections of the stanol fingerprints for the " $10 \%$ " and " $20 \%$ " water onto the $2 \mathrm{D}$ plane of the PCA developed by Derrien et al. (2011) were located in the human cluster during the whole course of the experiment (Figure 4).

\subsubsection{Oysters}

The values of the R1 ratio for the "blank", "10\%" and " $20 \%$ " oysters were lower than $0.03 \pm 0.02$ and therefore remained under the threshold of 0.50 indicative of human contamination (Figure 3d). Moreover, they did not greatly vary over time and, on average, did not differ (mean values for the three treatments: $0.02 \pm 0.00$ ).

The values of the R2 ratio for the "blank", "10\%" and "20\%" oysters were lower than $0.52 \pm 0.03$ and remained below the threshold of 0.73 indicative of human contamination (Figure 3e). In addition, they remained stable over time and were not different on average (mean values: $0.49 \pm 0.03$ for "blank" oysters, $0.51 \pm 0.02$ for " $10 \%$ " oysters and $0.51 \pm 0.02$ for " $20 \%$ " oysters).

Similarly, the values of the R3 ratio for the "blank", " $10 \%$ " and " $20 \%$ " oysters remained largely above the threshold of 0.20 (minimum value: 1.78) and were consequently not 
indicative of human contamination (Figure 3f). They did not differ between treatments and increased by $243 \%$ from the start to the end of the experiment.

In the PCA model developed by Derrien et al. (2011), stanol fingerprints of oysters from the "blank", " $10 \%$ " and ' $20 \%$ treatments were not specifically located in the human cluster, but between the human and bovine clusters (Figure 4).

\section{Discussion}

\subsection{Comparison between E. coli and fecal stanol kinetics}

\subsubsection{Water}

According to the European legislation on recreational water based on the E. coli concentration, the level of fecal contamination for " $10 \%$ " and " $20 \%$ " water decreased from highly contaminated levels until 48 hours to non-contaminated levels from 8 to 14 days. This pattern is in agreement with the patterns presented by Jeanneau et al. (2012), who observed the highest $E$. coli decay rate between 2 and 6 days of incubation followed by a lower decay rate until 13 days in seawater microcosms contaminated with a WWTP effluent, but without oysters. This reduction could be due to the sedimentation of E. coli associated with particles and/or predation by bacteriophage protozoans (Marty et al., 1995; Solecki et al., 2011).

The initial increase observed in the fecal stanol concentrations might be the result of i) the release of hydrophobic dissolved stanols from particles to water or ii) the exo-enzymatic hydrolysis of ester-bonded stanols by bacteria (Thoumelin et al., 1990; Marty et al., 1995). Similarly to the E. coli concentrations, there was a high decrease for fecal stanols in water 
between 2 and 8 days, like in the study by Jeanneau et al. (2012), who attributed this decrease to a combination of processes such as biodegradation and sedimentation.

These results shows that in these experimental conditions mimicking a short-term exposure to a human effluent, FIB E. coli and stanol markers in water are mainly degraded and/or removed during the course of the experiment (14 days).

\subsubsection{Oysters}

As previously observed in studies that investigated the kinetics of $E$. coli bioaccumulation by shellfish (Selegean et al., 2001; Jozic et al., 2012), oysters contaminated with WWTP effluent bioaccumulated E. coli within 1 hour in the present study. Escherichia coli concentrations in oysters remained higher than the European regulatory value until 2 days and then decreased below this value until 8 days. Escherichia coli concentrations remained relatively high in the contaminated oysters compared to the blanks until the end of the experiment while the contaminated water finally decreased to the blank values. These results are in agreement with those of Selegean et al. (2001) who conducted a similar experiment but on freshwater mussels contaminated by a WWTP effluent. Moreover, these results suggest that under these experimental conditions, the depuration process leading to the elimination of E. coli by defecation and lysozomal digestion of microorganisms (McHenery et al., 1979; Power and Collins, 1989; Love et al., 2010) from oyster tissues is not yet finished after 2 weeks. This depuration time is longer than those observed in depuration experiments in which fecally-contaminated oysters were allowed to depurate from E. coli in non-contaminated seawater (Buisson et al., 1981; Doré and Lees, 1995; Selegean et al., 2001; Pommepuy et al., 2003; Love et al., 2010), while in our experiment, oysters remained in fecally-contaminated water until ca. 6 days (Figure 1a). However, a comparison of the depuration kinetics observed here and in the previous studies should be considered cautiously since the depuration kinetics 
of shellfish are highly dependent on the species studied and on the experimental parameters such as water temperature, salinity, dissolved oxygen and particle concentrations and phytoplankton uptake (Richards, 1988; Pommepuy et al., 2003).

Among the four stanols focused upon in this study, two groups can be identified. The first comprises cholestanol and sitostanol: their concentration, and especially that of cholestanol, was naturally higher than that of the other stanols and remained high until the end of the experiment. Their respective reduction did not follow the pattern of E. coli. The second group comprises coprostanol and 24-ethylcoprostanol: their concentrations in oysters were lower than those of cholestanol and sitostanol and exhibited larger temporal variations. Moreover, their concentration in contaminated oysters followed quite similar patterns to that of E. coli: a first increase step several hours after contamination until 2 days followed by a decay step until 2 weeks. Although different in amplitude, the similarities between the kinetics of these two stanols and E. coli in oysters suggest that these compounds are indicative of the fecal contamination of oysters. Moreover, contrary to the E. coli concentration that did not reach its initial value after 2 weeks, the coprostanol and 24-ethylcoprostanol concentrations reached their respective initial values at the same time. This could be the result of a higher depuration efficiency of these compounds compared to that of E. coli.

4.2. Implications for the use of fecal stanols as markers of human fecal contamination

\subsubsection{Water}

As suggested by Furtula et al. (2012), the identification of human fecal contamination from wastewater by the use of fecal stanol ratios is more effective when several ratios are 
used. In the present study, the three ratios and the PCA model used on water contaminated by WWTP sewage confirmed their human fingerprint. This reinforces the usefulness of these ratios and/or the model to identify human fecal contamination in water (Derrien et al., 2012; Jeanneau et al., 2012; Furtula et al., 2012 and references therein). However, the sensibility of these ratios and the PCA model appears to differ. The three ratio values remained characteristic of human fecal contamination up to 2 to 8 days, while the projection of the stanol fingerprint onto the 2D plane of the PCA model remained in the human cluster up to the end of the experiment. These differences are probably due to the higher sensibility of the three stanol ratios to coprostanol variations than the PCA model. Indeed, the ratios are each based on the variations of two fecal stanols comprising the major stanol coprostanol, while the PCA model is based on the distribution of six stanols and is consequently less sensitive to coprostanol variations (Derrien et al., 2011).

\subsubsection{Oysters}

In oysters, the concentrations of coprostanol and 24-ethylcoprostanol, which are typical of feces and dominated the distribution of the raw WWTP effluent (Supplementary Table 1), were higher in contaminated oysters compared to non-contaminated ones (Figures 2e, f). The R1, R2 and R3 ratios and the PCA model applied to oysters could not be used to record a specific human fingerprint. Several assumptions can be put forward to explain these discrepancies. Firstly, the natural occurrence of cholestanol in oysters at high concentrations compared to that of coprostanol strongly decreased the relative importance of the latter with regards to the R1 ratio. As a consequence, the R1 values were much lower than the "human threshold", which makes this ratio inappropriate to identify a specific human fingerprint in 
oysters. Secondly, in terms of the R1 ratio, the natural occurrence of sitostanol in oysters at high concentrations compared to that of coprostanol meant that the R3 ratio was not able to identify a human fingerprint in oysters. In addition, the naturally high concentration of sitostanol in oysters compared to those of the other stanols used to build the PCA model (i.e. coprostanol, epicoprostanol, 24-ethylcoprostanol, 24-ethylepicoprostanol and campestanol) could produce PCA score plots for oysters that are primarily calculated from the sitostanol proportions, which makes the PCA model inadequate to identify a specific human fingerprint in oysters. Thirdly, the similar concentrations of both coprostanol and 24-ethylcoprostanol in oysters led to low values for the $\mathrm{R} 2$ ratio, which makes this ratio inappropriate to identify a specific human fingerprint in oysters. The similarity between the concentrations of these two compounds in oysters raises issues because in the surrounding contaminated water the concentration of coprostanol was at least three times higher than that of 24-ethylcoprostanol. A first hypothesis could be that the assimilation and/or depuration processes of these two compounds by oysters do not follow similar kinetics, resulting in large shifts in the R2 values from the surrounding water to oyster tissue. A second hypothesis could be that the concentrations of 24-ethylcoprostanol in oysters might have been overestimated because of its coelution with several compounds during GC-MS analysis (see the Experimental section in Harrault et al., 2014); in which case, the analytical pathway developed by Harrault et al. (2014), and especially the fractionation step, has to be improved.

In contrast to the present study, Harrault et al. (2014) found that oysters (C. gigas) sampled in a French bay presented a bovine fingerprint according to the currently used PCA model, which was in agreement with the activities of the surrounding watershed. The fact that oysters sampled in the field (Harrault et al., 2014) had a specific stanol fingerprint and that oysters artificially contaminated in the present batch experiment did not could be due to different exposure times to fecal contamination. Indeed, the present study was designed to 
represent a short-term exposure to a pulse of pollution by a WWTP effluent and the fecal coprostanol concentration decreased after 2 days in contaminated water. This decrease might not have occurred if the batches were continuously filled with WWTP sewage in order to represent constant pollution and the ratio values for the oysters used here might have reached a "human" value if the oysters were continuously supplied with the fecal stanol coprostanol from the surrounding water. This assumption could be investigated in a further study where oysters are exposed to constant concentrations of fecal stanols. On this basis, the theoretical kinetics of R1 for the " $20 \%$ " oysters was calculated by considering that the highest coprostanol accumulation rates (between $6 \mathrm{~h}$ and $24 \mathrm{~h}$ ) remained constant over time if the WWTP sewage discharge was continuous in our experiment (Figure 2e). As the cholestanol concentration did not vary over time in the "20\%" oysters (Figure $2 \mathrm{~g}$ ), its concentration was considered as being constant for the calculation of the R1 equation (mean of the $6 \mathrm{~h}$ and $24 \mathrm{~h}$ samples $=430.8 \mu \mathrm{g} / \mathrm{g} \mathrm{DW})$. The result presented in Figure 5 can be used to determine, under the previous assumptions, the theoretical exposure time of oysters to a continuous WWTP sewage discharge needed to bioaccumulate enough coprostanol to reach a human fingerprint with regards to their $\mathrm{R} 1$ ratios. The theoretical exposure time of $\mathrm{R} 1$ was reached at 38 days with a coprostanol concentration of $217.3 \mu \mathrm{g} / \mathrm{g}$ DW, which is very high compared to the concentrations observed in field studies (Sherwin et al., 1993; Cathum and Sabik, 2001; Gagné et al., 2001, 2002; Hellou et al., 2003; Yeats et al., 2008; Harrault et al., 2014) and seems practically unreachable in the laboratory. As a consequence, the stanol fingerprint does not seem to be suitable for the determination of human fecal contamination.

\section{Conclusion}


In this study, the ability of oysters to record specific human contamination through the use of fecal stanols was investigated by means of punctual artificial contamination of the surrounding seawater with a human WWTP effluent. The typical fecal stanols coprostanol and 24-ethylcoprostanol exhibited higher bioaccumulation in the contaminated oysters than in the non-contaminated ones, and their bioaccumulation kinetics were quite similar to that of the FIB E. coli, suggesting that these two compounds could be used as markers for the human fecal contamination of oysters. On the contrary, the naturally high concentrations of cholestanol and sitostanol in oysters and their different kinetics compared to that of E. coli make them unreliable to record fecal contamination.

Stanol fingerprints, such as the stanol ratios and PCA model that were successfully used to identify the human fingerprint in water, could not be used for this identification in oysters. This lack of specificity for the identification of a human fingerprint is the result of i) the high levels of cholestanol and sitostanol and ii) a large shift in the coprostanol concentration compared to that of 24-ethylcoprostanol in oysters compared to the surrounding water, probably due to either differences in the accumulation/depuration processes of these compounds or the limits of the analytical pathway used.

Thus this study shows that oysters are able to record a pulse of specific human contamination using specific fecal stanols. However, contrary to constant contamination, the stanol fingerprints of the oysters (ratios and PCA model) appear unreliable to identify a specific source of fecal contamination.

Last, the stanol fingerprint is a useful tool that can be used as a microbial source tracking toolbox to identify specific sources of fecally-contaminated water; however, the current analytical method of stanols in oysters might not allow the use of the stanol fingerprint as an applicable microbial source tracking tool in this type of matrix. This underlines the need to further investigate the analysis of stanols in a biological matrix. This limitation needs to be 
taken into account in further investigations of the application of stanol fingerprints to identify fecal contamination sources in shellfish harvesting areas.

\section{Acknowledgments:}

As part of the Riskmanche project (http://www.brighton.ac.uk/riskmanche/), this study was fully funded by the Interreg IV A France (Channel)-England cross-border European cooperation program. Dr. S. Mullin post-edited the English style (www.trad8.eu/us/saramullin.html). 


\section{References:}

Biache C. \& Philp R.P. (2013) The use of sterol distributions combined with compound specific isotope analyses as a tool to identify the origin of fecal contamination in rivers. Water research 47, 1201-8.

Blanch A.R., Belanche-Muñoz L., Bonjoch X., Ebdon J., Gantzer C., Lucena F., et al. (2006) Integrated analysis of established and novel microbial and chemical methods for microbial source tracking. Applied and environmental microbiology 72, 5915-26.

Buisson D., Fletcher G. \& Begg C. (1981) Bacterial depuration of the pacific oyster (Crassostrea gigas) in New-Zealand. New Zealand Journal of Science 24, 253-262.

Bull I.D., Lockheart M.J., Elhmmali M.M., Roberts D.J. \& Evershed R.P. (2002) The origin of faeces by means of biomarker detection. Environment International 27, 647-654.

Cathum S. \& Sabik H. (2001) Determination of steroids and coprostanol in surface water, effluent and mussel using gas chromatography-mass spectrometry. Chromatographia 53, S394-S399.

Charles F., Grémare A., Amouroux J.-M. \& Cahet G. (1992) Filtration of the enteric bacteria Escherichia coli by two filter-feeding bivalves, Venus verrucosa and Mytilus galloprovincialis. Marine Biology 113, 117-124.

Derrien M., Jarde E., Gruau G. \& Pierson-Wickmann A.-C. (2011) Extreme variability of steroid profiles in cow feces and pig slurries at the regional scale: implications for the use of steroids to specify fecal pollution sources in waters. Journal of agricultural and food chemistry 59, 7294-302. 
Derrien M., Jardé E., Gruau G., Pourcher A.M., Gourmelon M., Jadas-Hécart A., et al. (2012) Origin of fecal contamination in waters from contrasted areas: stanols as Microbial Source Tracking markers. Water research 46, 4009-16.

Dore W. \& Lees D. (1995) Behavior of Escherichia coli and male-specific bacteriophage in environmentally contaminated bivalve mollusks before and after depuration. Applied and Environmental Microbiology 61, 2830-2834.

Fong T.-T. \& Lipp E.K. (2005) Enteric viruses of humans and animals in aquatic environments: health risks, detection, and potential water quality assessment tools. Microbiology and molecular biology reviews : MMBR 69, 357-71.

Furtula V., Liu J., Chambers P., Osachoff H., Kennedy C. \& Harkness J. (2011) Sewage Treatment Plants Efficiencies in Removal of Sterols and Sterol Ratios as Indicators of Fecal Contamination Sources. Water, Air, \& Soil Pollution 223, 1017-1031.

Gagné F., Blaise C., Aoyama I., Luo R., Gagnon C., Couillard Y., et al. (2002) Biomarker study of a municipal effluent dispersion plume in two species of freshwater mussels. Environmental toxicology 17, 149-59.

Gagné F., Blaise C., Lachance B., Sunahara G.I. \& Sabik H. (2001) Evidence of coprostanol estrogenicity to the freshwater mussel Elliptio complanata. Environmental Pollution 115, $97-106$.

Glassmeyer S.T., Furlong E.T., Kolpin D.W., Cahill J.D., Zaugg S.D., Werner S.L., et al. (2005) Transport of Chemical and Microbial Compounds from Known Wastewater Discharges: Potential for Use as Indicators of Human Fecal Contamination. Environmental Science \& Technology 39, 5157-5169. 
Gourmelon M., Caprais M.P., Le Mennec C., Mieszkin S., Ponthoreau C. \& Gendronneau M. (2010) Application of library-independent microbial source tracking methods for identifying the sources of faecal contamination in coastal areas. Water Science \& Technology 61, 1401.

Harrault L., Jardé E., Jeanneau L. \& Petitjean P. (2014) Development of the analysis of fecal stanols in the oyster Crassostrea gigas and identification of fecal contamination in shellfish harvesting areas. Lipids 49, 597-607.

Hellou J., Yeats P., Steller S. \& Gagné F. (2003) Chemical contaminants and biological indicators of mussel health during gametogenesis. Environmental Toxicology and Chemistry 22, 2080.

Hundesa A., Maluquer de Motes C., Bofill-Mas S., Albinana-Gimenez N. \& Girones R. (2006) Identification of human and animal adenoviruses and polyomaviruses for determination of sources of fecal contamination in the environment. Applied and environmental microbiology 72, 7886-93.

Jardé E., Gruau G. \& Jaffrezic A. (2009) Tracing and Quantifying Sources of Fatty Acids and Steroids in Amended Cultivated Soils. Journal of Agricultural and Food Chemistry 57, 6950-6956.

Jardé E., Gruau G., Mansuy-Huault L., Peu P. \& Martinez J. (2006) Using Sterols to Detect Pig Slurry Contribution to Soil Organic Matter. Water, Air, and Soil Pollution 178, 169178.

Jeanneau L., Jardé E. \& Gruau G. (2011) Influence of salinity and natural organic matter on the solid phase extraction of sterols and stanols: application to the determination of the human sterol fingerprint in aqueous matrices. Journal of chromatography. A 1218, 251320. 
Jeanneau L., Solecki O., Wéry N., Jardé E., Gourmelon M., Communal P.-Y., et al. (2012) Relative decay of fecal indicator bacteria and human-associated markers: a microcosm study simulating wastewater input into seawater and freshwater. Environmental science \& technology 46, 2375-82.

Jozic S., Solic M. \& Krstulovic N. (2012) The accumulation of the indicator bacteria Escherichia coli in mussels (Mytilus galloprovincialis) and oysters (Ostrea edulis) under experimental conditions. Acta Adriatica 53, 353-361.

Leeming R., Ball A., Ashbolt N. \& Nichols P. (1996) Using faecal sterols from humans and animals to distinguish faecal pollution in receiving waters. Water Research 30, 28932900.

Leeming R., Latham V., Rayner M. \& Nichols P. (1997) Detecting and distinguishing sources of sewage pollution in Australian inland and coastal waters and sediments. In: Molecular markers in environmental geochemistry, ACS Sympos. (Ed. R. Eganhouse), pp. 306-319. American Chemical Society, 1155 sixteenth St Nw., Washington, DC 20036 USA.

Love D.C., Lovelace G.L. \& Sobsey M.D. (2010) Removal of Escherichia coli, Enterococcus fecalis, coliphage MS2, poliovirus, and hepatitis A virus from oysters (Crassostrea virginica) and hard shell clams (Mercinaria mercinaria) by depuration. International journal of food microbiology 143, 211-7.

McHenery J.G., Birkbeck T.H. \& Allen J.A. (1979) The occurrence of lysozyme in marine bivalves. Comparative Biochemistry and Physiology Part B: Comparative Biochemistry 63, 25-28.

Marty Y., Quéméneur M., Aminot A. \& Le Corre P. (1996) Laboratory study on degradation of fatty acids and sterols from urban wastes in seawater. Water Research 30, 1127-1136. 
Mauffret A., Mieszkin S., Morizur M., Alfiansah Y., Lozach S. \& Gourmelon M. (2013) Recent innovation in microbial source tracking using bacterial real-time PCR markers in shellfish. Marine pollution bulletin 68, 21-9.

Mieszkin S., Caprais M.P., Le Mennec C., Le Goff M., Edge T.A. \& Gourmelon M. (2013) Identification of the origin of faecal contamination in estuarine oysters using Bacteroidales and F-specific RNA bacteriophage markers. Journal of applied microbiology 115, 897-907.

Pommepuy M., Caprais M.-P., Le Saux J.-C., Le Mennec C., Parnaudeau S., Madec Y., et al. (2003) Evaluation of viral shellfish depuration in a semi-professional tank. In: 4th International Conference on Molluscan Shellfish Safety. pp. 485-499. Santiago de Compostella.

Power U. \& Collins J. (1989) Differential depuration of poliovirus, Escherichia coli, and a coliphage by the common mussel, Mytilus edulis. Applied and Environmental Microbiology 55, 1386-1390.

Richards G. (1988) Microbial purification of shellfish - a review of depuration and relaying. Journal of Food Protection 51, 218-251.

Riou P., Le Saux J.C., Dumas F., Caprais M.P., Le Guyader S.F. \& Pommepuy M. (2007) Microbial impact of small tributaries on water and shellfish quality in shallow coastal areas. Water research 41, 2774-86.

Selegean J., Kusserow R., Patel R., Heidtke T. \& Ram J. (2001) Using zebra mussels to monitor Escherichia coli in environmental waters. Journal of Environmental Quality 30, $171-179$. 
Shah V.G., Dunstan R.H., Geary P.M., Coombes P., Roberts T.K. \& Von Nagy-Felsobuki E. (2007) Evaluating potential applications of faecal sterols in distinguishing sources of faecal contamination from mixed faecal samples. Water research 41, 3691-700.

Sherwin M.R., Van Vleet E.S., Fossato V.U. \& Dolci F. (1993) Coprostanol (5ß-cholestan$3 \beta-\mathrm{ol})$ in lagoonal sediments and mussels of Venice, Italy. Marine Pollution Bulletin 26, $501-507$.

Simpson J.M., Santo Domingo J.W. \& Reasoner D.J. (2002) Microbial Source Tracking: State of the Science. Environmental Science \& Technology 36, 5279-5288.

Solecki O., Jeanneau L., Jardé E., Gourmelon M., Marin C. \& Pourcher A.M. (2011) Persistence of microbial and chemical pig manure markers as compared to faecal indicator bacteria survival in freshwater and seawater microcosms. Water research $\mathbf{4 5}$, $4623-33$.

Soller J., Embrey M., Tuhela L., Ichida A. \& Rosen J. (2010) Risk-based evaluation of Escherichia coli monitoring data from undisinfected drinking water. Journal of environmental management 91, 2329-35.

Thoumelin G., Marty Y., Lecorre P. \& Aminot A. (1990) laboratory investigation of the degradation of organic-matter in estuarine and coastal waters - sterols variations. Oceanologica Acta 13, 53-60.

Tyagi P., Edwards D.R. \& Coyne M.S. (2009) Distinguishing between human and animal sources of fecal pollution in waters: a review. International Journal of Water 5, 15.

Vantarakis A., Venieri D., Komninou G. \& Papapetropoulou M. (2006) Hybridisation of F+ RNA coliphages detected in shellfish samples with oligonucleotide probes to assess the origin of microbiological pollution of shellfish. Water Science \& Technology 54, 219. 
Vogel J.R., Stoeckel D.M., Lamendella R., Zelt R.B., Santo Domingo J.W., Walker S.R., et al. (2007) Identifying fecal sources in a selected catchment reach using multiple sourcetracking tools. Journal of environmental quality 36, 718-29.

Wolf S., Hewitt J. \& Greening G.E. (2010) Viral multiplex quantitative PCR assays for tracking sources of fecal contamination. Applied and environmental microbiology 76, $1388-94$.

Yeats P., Gagné F. \& Hellou J. (2008) Body burden of contaminants and biological effects in mussels: an integrated approach. Environment international 34, 254-64. 
Table1 : Mean values of physico-chemical parameters over the whole experiment. Uncertainties are standard deviations.

\begin{tabular}{|c|c|c|c|}
\hline Treatment & Blank & $10 \%$ & $20 \%$ \\
\hline$p H$ & $7.98 \pm 0.05$ & $8.03 \pm 0.03$ & $8.10 \pm 0.06$ \\
\hline$O 2(\%)$ & $94.1 \pm 7.4$ & $92.2 \pm 8.9$ & $90.3 \pm 10.1$ \\
\hline Salinity (g/kg) & $34.5 \pm 0.7$ & $31.8 \pm 1.2$ & $29.0 \pm 2.2$ \\
\hline$T\left({ }^{\circ} \mathrm{C}\right)$ & $13.1 \pm 1.4$ & $12.9 \pm 1.4$ & $12.6 \pm 1.4$ \\
\hline$D O C(m g / L)$ & $2.51 \pm 1.31$ & $3.75 \pm 2.05$ & $4.12 \pm 1.07$ \\
\hline$S P M(m g / L)$ & $20.1 \pm 10.5$ & $22.3 \pm 11.1$ & $27.2 \pm 14.6$ \\
\hline
\end{tabular}


Figure 1: Temporal variations of the concentration of Escherichia coli in waters and oysters expressed as colony forming unit (CFU) $\log _{10}$ units/100 mL and $\log _{10}$ units/100 g of flesh, respectively. Open triangles are blanks, grey squares ' $10 \%$ ' treatment and black circles ' $20 \%$ ' treatment. Errors are standard deviations $(\mathrm{n}=3)$. Horizontal dotted lines represent European fecal contamination thresholds for water and oyster of sufficient quality $(2.7 \log \mathrm{CFU} / 100 \mathrm{~mL}$ and $3.7 \log$ CFU/100 g, respectively).
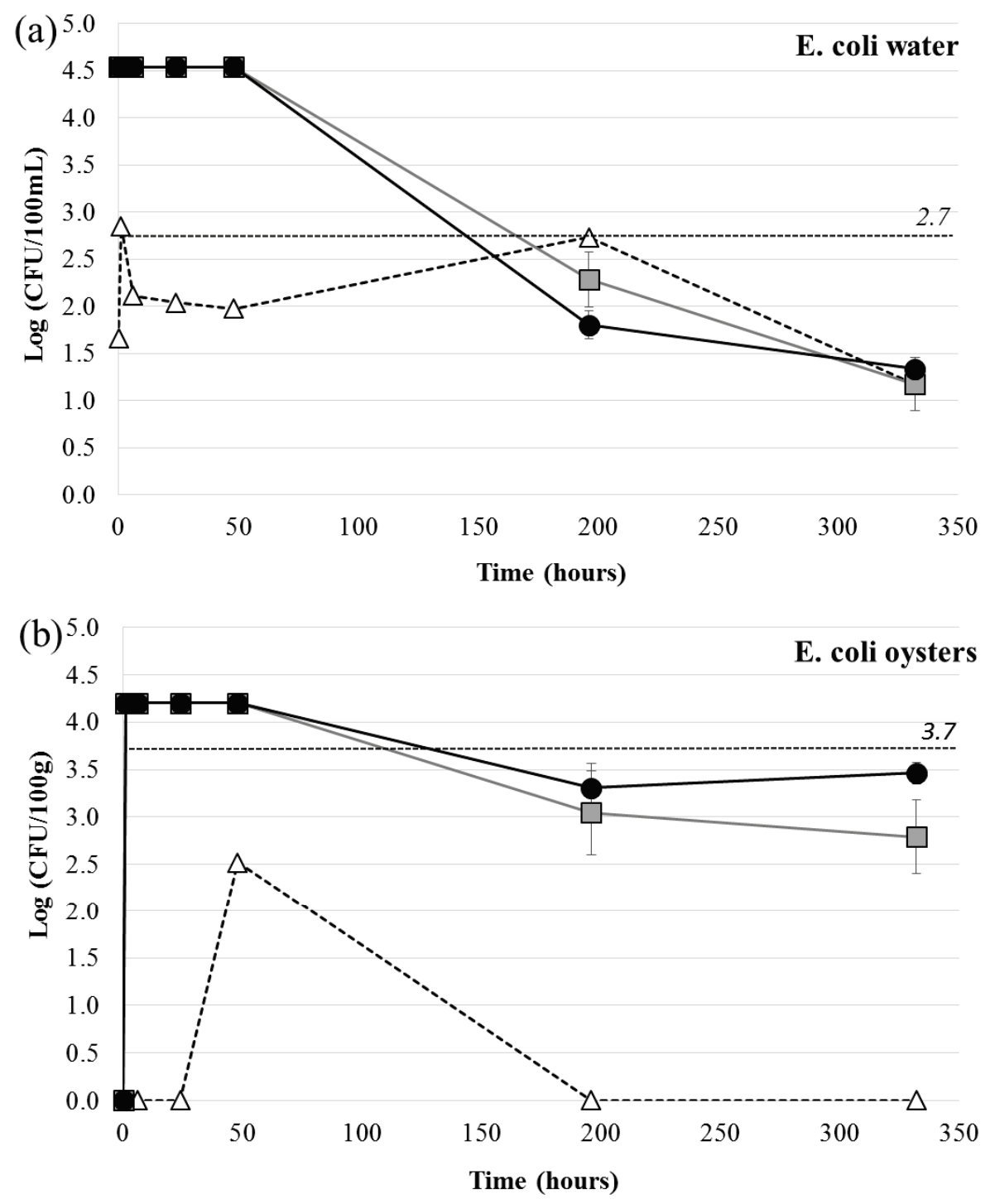
Figure 2: Temporal variations of the concentrations of coprostanol, 24-ethylcoprostanol, cholestanol and sitostanol of water $(\mu \mathrm{g} / \mathrm{L})$ and oysters $(\mu \mathrm{g} / \mathrm{g})$. Open triangles are blanks, grey squares ' $10 \%$ ' treatment and black circles ' $20 \%$ ' treatment. Errors are standard deviations (n $=3$ ).
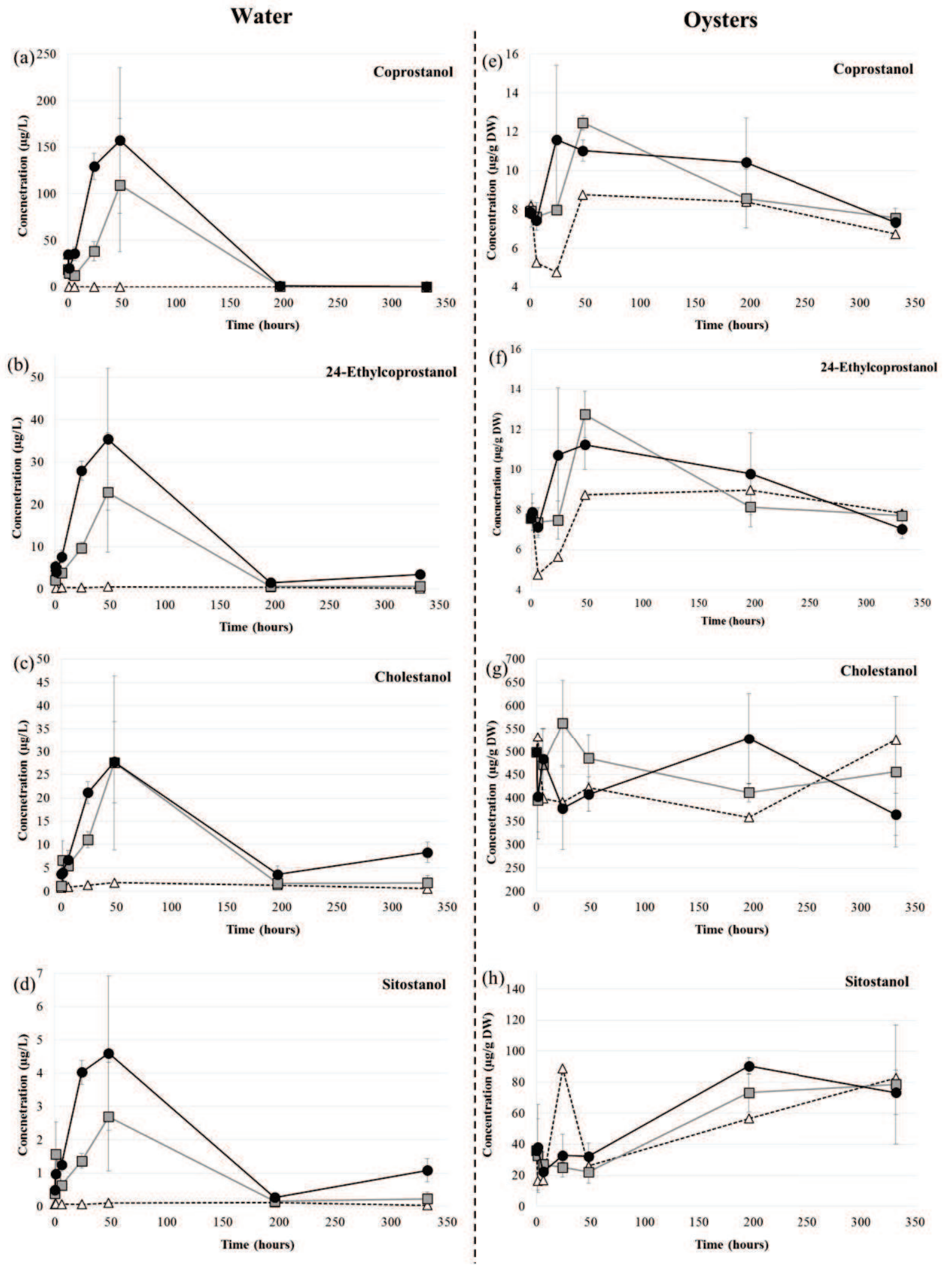
Figure 3 : Temporal variations of stanol ratios in water and oysters over time : (a, d) R1 = coprostanol/ cholestanol, (b, e) R2 = coprostanol/(coprostanol + 24-ethylcoprostanol) and (c, f) R3 = sitostanol/ coprostanol. Open triangles are blanks, grey squares ' $10 \%$ ' treatment and black circles '20\%' treatment. Horizontal dashed lines represent the upper limits above which each ratio is indicative of a major human contamination. Vertical dotted lines represent the theoretical time at which ratios become non-indicative of a human contamination. Errors are standard deviations $(\mathrm{n}=3)$.

\section{Water}

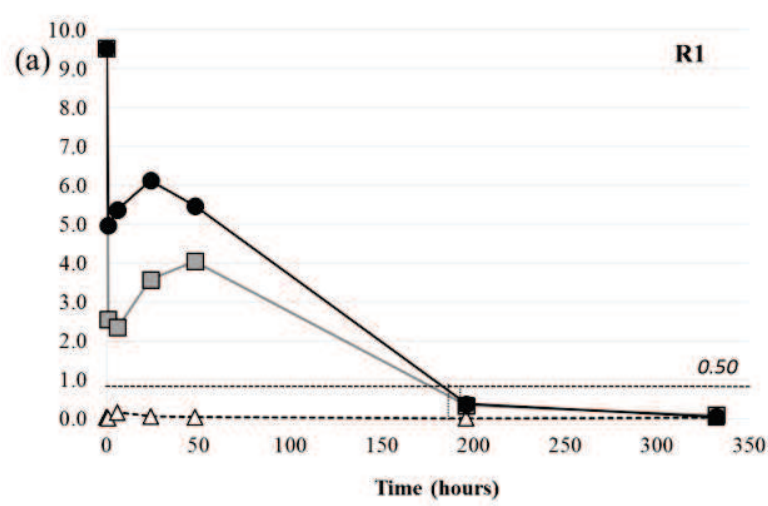

(b) 1.0

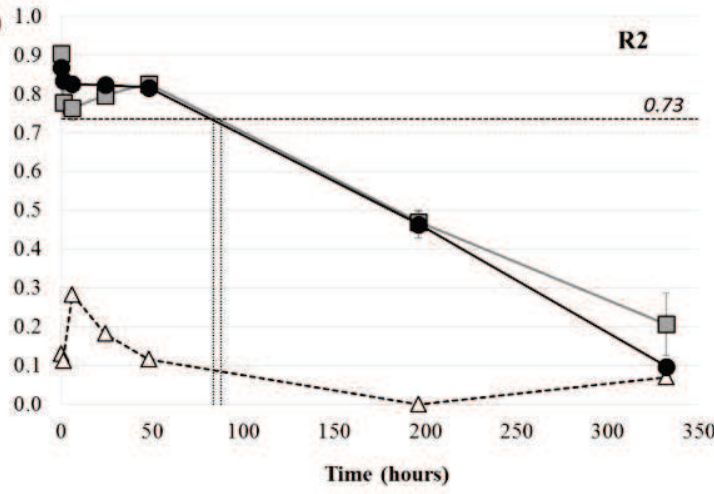

(c) 3.5

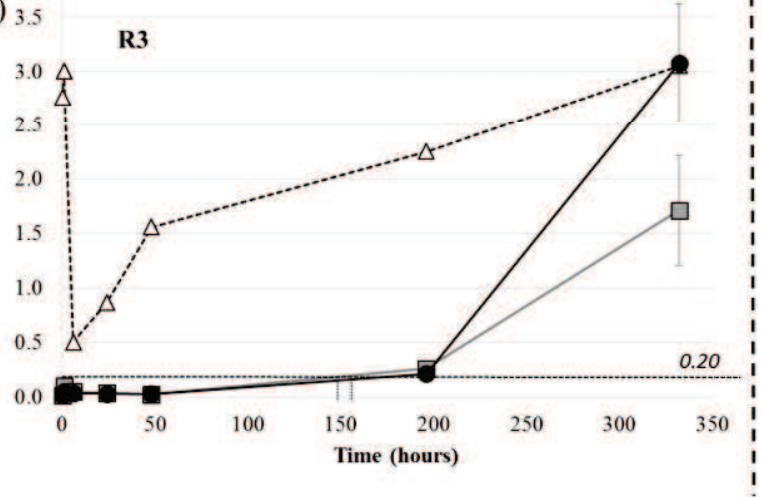

\section{Oysters}

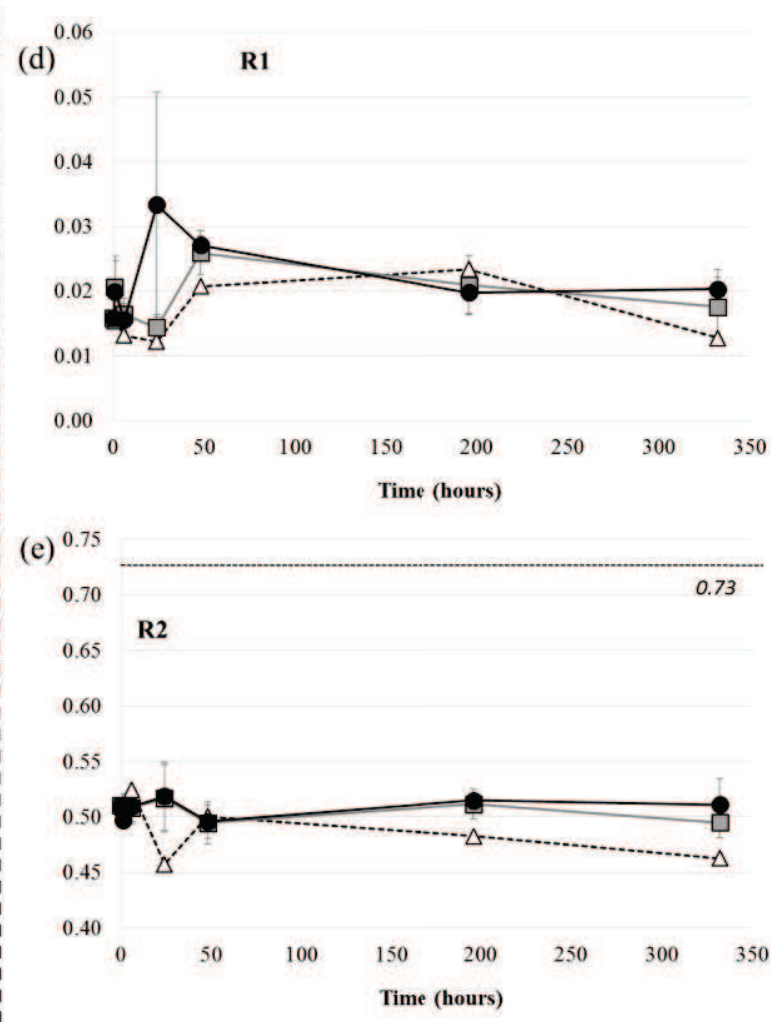

(f) ${ }^{16.00}$

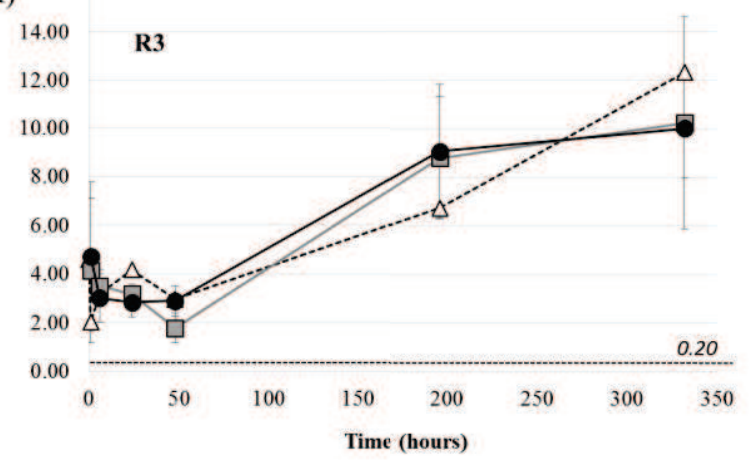


Figure 4: Plot of the principal component analysis comparing the 88 source samples and water and oyster samples using the 6 most discriminant stanol compounds proposed by Derrien et al. (2012). Sample fingerprints were not graphically distinguished between treatments and time. F1 axis: principal component 1; F2 axis: principal component 2.

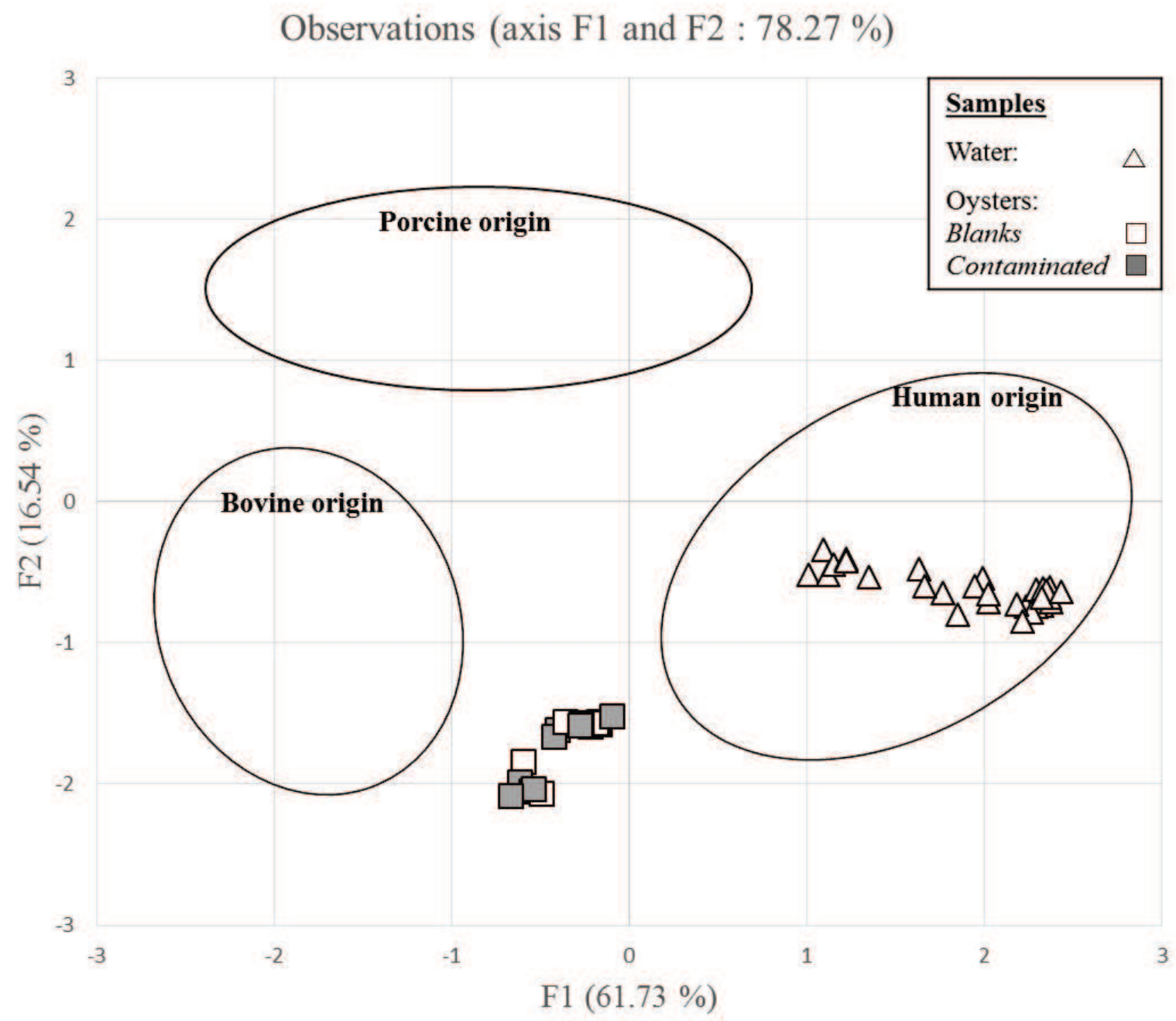


Figure 5 : Theoretical kinetics of stanol ratios R1 (coprostanol/ cholestanol) of oysters from '20\%' treatment. Horizontal dashed lines represent the upper limits above which R1 is indicative of a major human contamination. Vertical dotted line represent the theoretical time at which $\mathrm{R} 1$ become indicative of a human contamination.

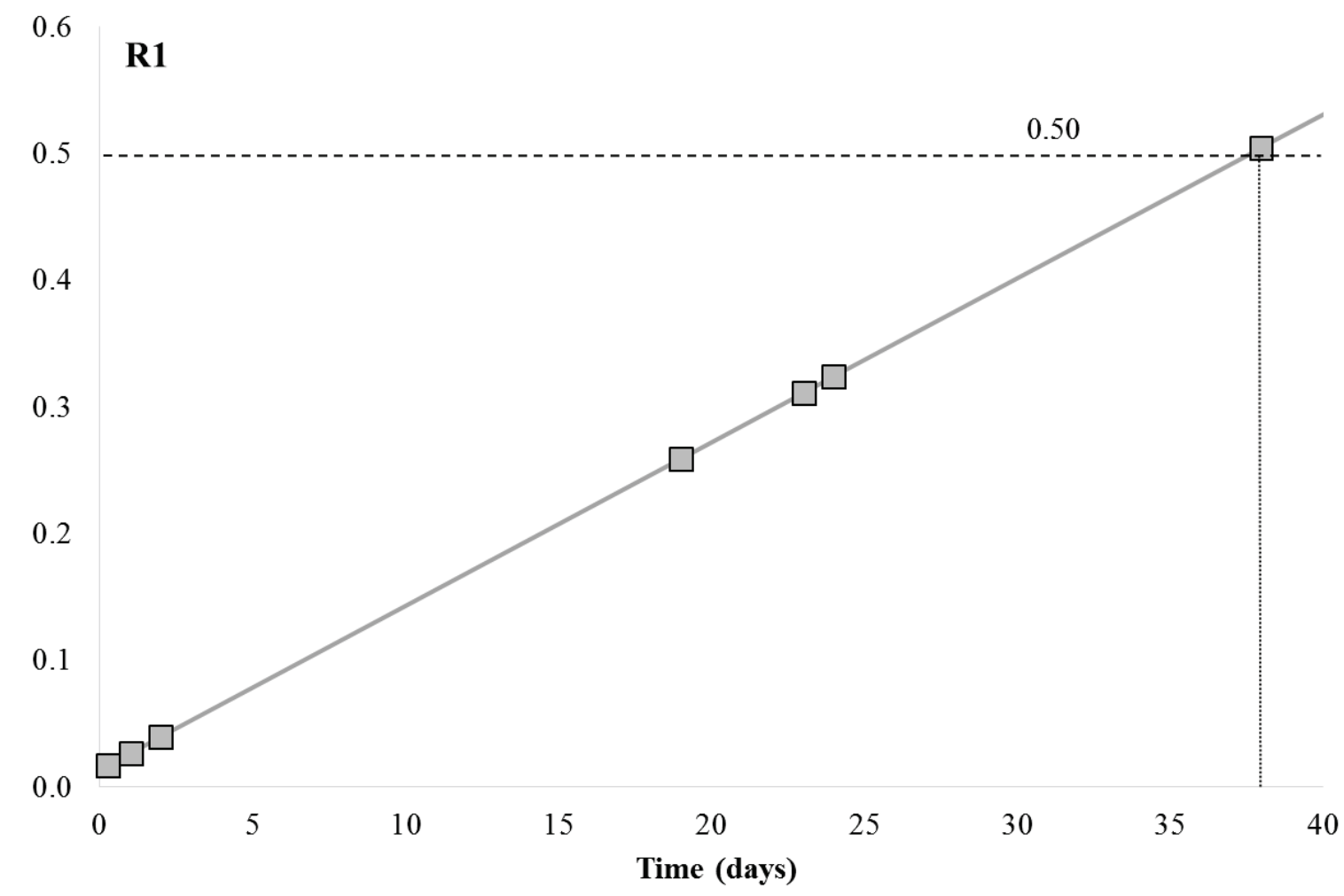


Supplementary Data
Click here to download Supplementary Data: Supplementary Tables Harrault MBP.docx 